\title{
The Effect of Inventory Control Systems on Organisational Performance in the Mining Sector of Zimbabwe
}

\author{
Dumisani Mawonde and Casper Demberere \\ Bindura University of Science Education, Bindura, Zimbabwe
}

\begin{abstract}
The aim of this study was to determine the effect of inventory control systems on organisational performance in the mining sector of Zimbabwe. A quantitative survey approach was used and a sample of 203 mining companies was used for data analysis. Structural Equation Modelling (SEM) was run in Analysis for Moment Structures (AMOS) version 22 to test the formulated hypotheses. The findings of the study were that, inventory control systems have both positive direct and positive indirect effect on organisational performance. The study concluded that, inventory control systems have a positive effect on organisational performance in the mining sector of Zimbabwe. The study recommended mining companies in Zimbabwe to implement modern computerised inventory control systems for effective inventory management in order to enhance organisational performance.
\end{abstract}

Key words: inventory, inventory control systems, organisational performance

\section{INTRODUCTION}

$\mathrm{I}^{\mathrm{n}}$ nventory control systems are effective in maintaining optimum inventory levels in firms to avoid either the shortage of stock or to reduce excess inventories. Most mining companies in Zimbabwe are inefficient because they use primitive inventory control systems such as spreadsheets and other manual processes to manage, reconcile and report their inventories (Zuva \& Choga, 2016).

The mining sector is one of the key drivers of the economy as it ranks among the top three contributors of Gross Domestic Product (GDP), (Zimbabwe Economic Report, 2018).So, the importance of improving the performance of mining companies cannot be overlooked. As the economy is deteriorating due to fiscal and monetary misalignments and chronic foreign currency shortages, there are massive shortages of spare parts and materials in the local market that mining companies succumb to inventory shortages and this is disturbing mining operations. For that reason, many mining companies are buying inventories in large quantities from foreign markets in order to manage the volatility of prices and exchange rates (Zimbabwe Economic Report, 2018). Therefore, the use of efficient inventory control systems in the mining companies is deemed to facilitate the timely delivery of spares parts and the effective management of available inventories in order to service the mining machinery and equipment so as to avoid unnecessary breakdowns and keep the mining operations running.

More so, there has been a lot of expectation on mining companies operating in Zimbabwe to operate above full capacity in order to generate more profits to support the growth of the economy (Chamber of Mines of Zimbabwe, 2015). Nonetheless, mining companies are underperforming that a lot of interest is generated from various stakeholders including the government, who on several occasions have questioned on a number of issues concerning the performance of the sector (The State of the Mining Industry Survey Report, 2018).According to the Zimbabwe Economic Report, (2018), mining companies are underperforming because they are operating below full capacity. The underperformance of mining companies is attributed to factors such as capital shortage, very old machinery, frequent machine breakdowns, high operating costs including the shortage and high cost of materials which have been seen as the limiting factors undermining capacity utilisation (Confederation of Zimbabwe Industries Mining Sector Survey Report, 2018). There is evidence that for a period of 10 years mining companies have been operating below $40 \%$ of capacity utilisation which has negatively hindered them to achieve their objectives particularly the profitability objective.

Since the majority of mining companies operating in Zimbabwe use primitive inventory control systems to manage inventories, this has been for a long time causing high inventory costs which have increased operating costs thereby undermining capacity utilisation and negatively affecting the profitability objective (State of The Mining Industry Survey Report, 2018). Therefore, failure to reconcile inventories has been interrupting mining operations and thus negatively affecting the production output. It is against this background that the researcher was encouraged to carry out a study on the effects of inventory control systems on organisational performance in the mining sector of Zimbabwe.

\section{LITERATURE REVIEW}

\subsection{Inventory Control Systems}

There are numerous inventory control systems in practice that range from simple to very complicated systems. Firms must 
make sure that the inventory control systems they implement are the most efficient and effective.

Firstly, the Enterprise Resource Planning (ERP) system is an inventory control system for the effective planning and controlling of all resources required to obtain, create, transport and account for customer orders in producing, distribution or service organisation (American Production and Inventory Control Society, 2001). The advantages of an ERP system are that, it normalises company procedures, integrates facilities and data, computerise dealing processes, increase the flexibility, lessens the number of employees, strengthen the globalisation system and resolves problems.

Secondly, the Continuous Review System (CRS) which is also referred to as the fixed point reorder system is an inventory replenishment policy which points out that inventory is continuously tracked and ordering according to lot size is done when the inventory level reaches the entrusted inventory reorder point (Setyaningsih \& Basri, 2013). The benefits of using CRS are that, it allows updating inventory counts in real time and so is easier to know when to reorder items in the future.

The third inventory control system to be described is the Periodic Review System (PRS). With the periodic review system, inventory position is reviewed after a fixed period of time for instance after every two weeks whereas on continuous review, inventory position is reviewed on a perpetual basis that is each time a withdrawal on the inventory is made. The benefits of using PRS is the minimisation of time for the management of a company to analyse the amount of inventory, so they can use that time to consider other aspects of business.

Furthermore, the Just in Time (JIT) technique is a Japanese philosophy that is linked with assembling which comprises having the right things in the right quality and amount in the correct place and at the appropriate time. Hutchins (1999) opines that, the key purpose of JIT technique is the achievement of zero stock, not merely inside the bounds of a single organisation at the end of the day all through the entire production system. The use of the JIT technique brings about the increase in quality, profitability, and effectiveness, improved correspondence, and minimisations in expenses and squanders.

Additionally, the Economic Order Quantity is another inventory control system that controls inventory in a logical way so that the organisation can be able to know when to order and how much to order (Bowersox, 2002). This technique enables organisations to have unimportant limit costs or zero inside their circulation focuses. Along these lines, as associations attempt to improve the stock management, the EOQ and Re-Order Point (ROP) are essential instruments that associations can make use of.

In addition, another inventory control systems is the Materials Requirements Planning (MRP). An MRP system consists of a set of sensibly connected procedures, decision rules, and records intended to explain a master production schedule into time-phased net requirements and the intended coverage of such requirements for each stock point (Orlicky, 1975). MRP systems seek to overcome the limitation of traditional inventory control systems in a manufacturing environment. According to Silver, (1985), MRP systems use the dependent nature of demands for components, they take into account the time changing nature of the requirements and they bring together stock points that deal with the same operation.

Lastly, there is also the Distribution Requirements Planning (DRP), an inventory control system which doubles of MRP systems. DRP is merely the application of the MRP principles and techniques to the management of inventories in distribution (Martin, 1983). In DRP systems for every downstream stock point a master schedule with its gross requirements is developed. Through allocation of existing inventory levels, net requirements for the stock point are achieved. These net requirements are translated to planned receipts and planned orders respectively. The planned orders are translated to gross requirements for the next upstream inventory points. DRP is a usual expansion of MRP that addresses the problem of using independent control of the same product at different locations.

\subsection{Conceptual Framework}

The following is the conceptual framework of this study;

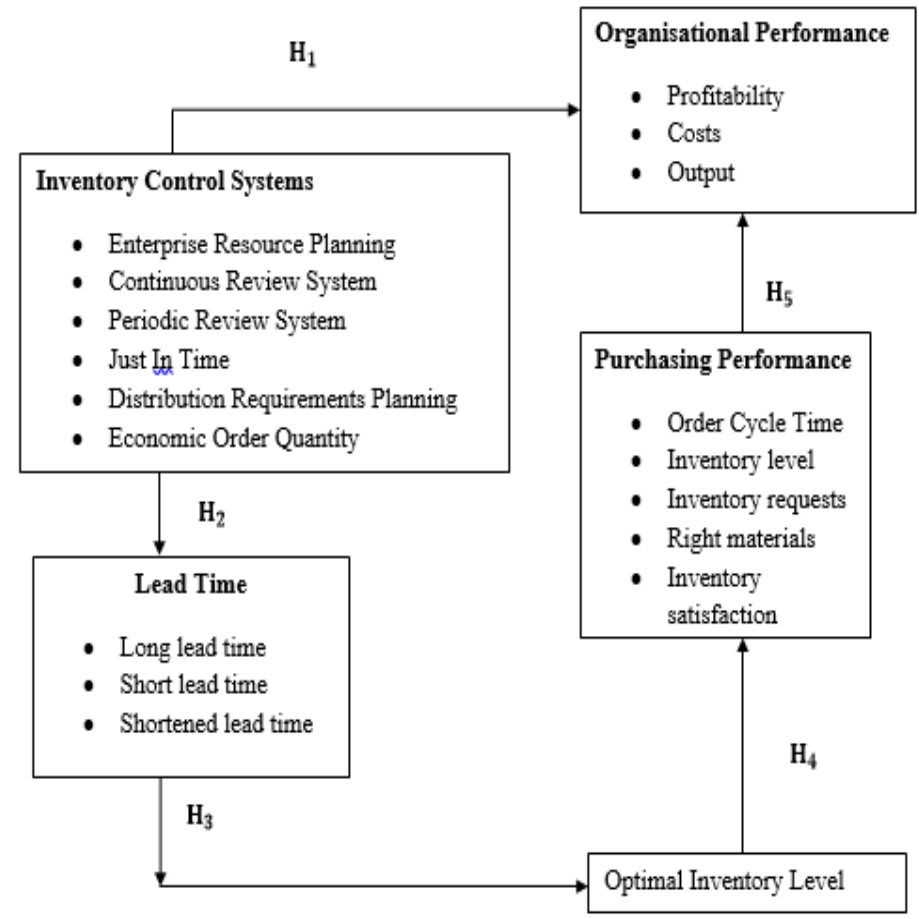

Source: Author (2021)

\subsection{Hypotheses of the study}

The following is the literature that suggests the relationship between inventory control systems, lead time, optimum 
inventory levels, purchasing performance and organisational performance:

\subsubsection{Inventory control systems and organisational performance}

Inventory management is important to mining organisations. Silas (2006) put forward that inventory management plays a critical role in determining organisational performance. This means that the level of inventory which is maintained by an organisation determines its performance. Therefore, mining organisations that are operating in Zimbabwe values the use of effective inventory control systems in managing inventories as this help them to enhance their performance. Mining companies use inventory control systems to avoid either excess inventory levels or stock-outs and this help them to minimise inventory costs. Therefore, inventory control systems assist mining companies to keep optimum inventory levels and improve their performance.

Based on the above, the following hypotheses were formulated:

$\mathbf{H}_{\mathbf{1}}$ : Inventory control systems have a direct positive effect on organisational performance.

$\mathbf{H}_{\mathbf{1 b}}$ : Inventory control systems have an indirect positive effect on organisational performance.

\subsubsection{Inventory control systems and lead time}

Waters (2003) defines lead time as the time between placing an order and having the materials arrive in stock. The shorter the lead time, the more suitable it is for buyers because they can wait until the last possible moment before entering an order for delivery at a predetermined time (Feinstein and Stefanelli, 2000). On the other hand, Torres and Mahmoodi (2010) state that a longer lead time affects the safety stock which affects the optimal inventory levels. Therefore, using appropriate inventory control systems facilitate the attainment of shorter lead times which help mining companies to maintain optimal inventory levels hence minimising inventory costs.

Based on the above, the following hypothesis was formulated:

$\mathbf{H}_{2}$ : Inventory control systems have a positive effect on lead time.

\subsubsection{Lead time and optimum inventory levels}

Optimum inventory levels are the ideal and most favourable levels of inventories that kept by a firm to minimise either inventory ordering or inventory holding costs. Saleemi (1993) opines that when a firm keeps optimum inventory levels, it enjoys the benefits of fewer risks of deterioration and obsolescence, and reduced cost of insurance among others. The exercise of monitoring inventory levels using inventory control systems allow firms to keep away from tying up surplus investment in unused stock at the expense of lucrative projects (Lazaridis and Tryponidis, 2006). Accordingly, inventory control systems assist mining companies to monitor the lead time and to maintain optimum inventory levels so as to avoid unwanted inventory costs and interrupted production processes.

Based on the above, the following hypothesis is formulated:

$\mathbf{H}_{3}$ : Lead time has a positive effect on optimal inventory level.

\subsubsection{Optimum inventory levels and purchasing performance}

Inventory control systems assist firms to maintain optimum inventory levels (Mentzer, 2000). When a firm maintains optimum inventory levels, it enhances the purchasing performance as follows: order cycle time is reduced, inventory is distributed effectively, there is timely discovery of inventory requests and inventories are received on time from suppliers. For that reason, improving purchasing performance leads to the minimisation of total operating costs which eventuality results in increase in production output and profitability (Lin et al. 2002).

Based on the above, the following hypothesis is formulated:

$\mathbf{H}_{4}$ : Optimal inventory level has a positive effect on purchasing performance.

\subsubsection{Purchasing performance and organisational} performance

Carr and Pearson, (2002) opines that purchasing performance affects organisational performance. On the other hand, Rossetti and Choi (2005) put forward that the level of performance of the purchasing function of a firm determines the level of the performance of that firm. Inventory control systems play a very important role in improving the performance of the purchasing function in many organisations (Paulraj, 2006). This study values the importance of improving the performance of the purchasing departments in mining companies as this is deemed important in enhancing organisational performance.

Based on the above explanation, the following hypothesis was proposed:

$\mathbf{H}_{\mathbf{5}}$ : Purchasing performance has a positive effect on organisational performance.

\section{METHODOLOGY OF THE STUDY}

The study has used a quantitative survey approach to enable the study to accommodate a large sample size, use statistical analysis and tap into factors and relationships not directly measurable (Hair, Bush, \& Ortinau, 2003). The target population of this study consisted of registered artisanal and small scale miners and big mining companies that are operating in the mining sector of Zimbabwe. Therefore, the total population targeted was 650 registered companies (The State of the Mining Industry Survey Report, 2020). The sample size which was used for data analysis comprised of 203 responses. The questionnaire with structured questions was organised using a Likert scale ranging from 1 to 5 points 
$(1=$ strongly disagree, $2=$ disagree, $3=$ Uncertain, $4=$ agree, $5=$ strongly agree). The Structural Equation Modelling (SEM) was used to examine the relationship among the study variables and the Statistical Package for Social Sciences (SPSS) version 22 and Analysis of Moment Structures (AMOS) version 22 software's were used to calculate the correlation between constructs and to tabulate data.

\section{FINDINGS}

\subsection{Results of Proposed Structural Equation Model and Hypothesis Testing.}

Table 4.1 below shows the regression weights which show the results of hypothesis testing.

Table 4.1 Regression Weights

\begin{tabular}{|c|c|c|c|c|c|c|}
\hline \multicolumn{2}{|c|}{ Parameter } & Estimate & Lower & Upper & \multicolumn{2}{c|}{ P } \\
\hline Lead time & $<--$ & Inventory control systems & .119 & .033 & .217 & .020 \\
\hline Optimal inventory level & $<--$ & Lead time & 1.693 & .998 & 4.735 & .009 \\
\hline Purchasing performance & $<---$ & Optimal inventory levels & .106 & .046 & .235 & .009 \\
\hline Organisational performance & $<---$ & Purchasing performance & .490 & -.003 & 1.193 & .104 \\
\hline Organisational performance & $<--$ & Inventory control systems & .641 & .332 & 1.026 & .010 \\
\hline
\end{tabular}

Source: Primary data (2021)

The first hypothesis $\left(\mathbf{H}_{\mathbf{1 a}}\right)$, states that inventory control systems have a direct positive effect on organisational performance. The results on table 4.1 above support the hypothesis; which is shown by the standardised coefficient with a value of 0.641 which is positive and is statistically significant at $\mathrm{p}<.05(0.010)$. Therefore, the implementation of inventory control systems directly help to improve the performance of organisations in the mining sector of Zimbabwe through increasing profitability, output level, and cost efficiency. The results are consistent with the findings of a study by Ukpere (2014), in Nigeria that inventory management systems are important to achieving organisational performance.

The second hypothesis $\left(\mathbf{H}_{2}\right)$, states that inventory control systems have a positive effect on lead time. The results on table 4.1 above support the hypothesis which is confirmed by a standardised coefficient with a value of 0.119 which is positive and is statistically significant at $\mathrm{p}<.05(0.020)$. Therefore, it means that the implementation of inventory control systems may have a positive and significant effect on lead time.

The third hypothesis $\left(\mathbf{H}_{3}\right)$,states that lead time has a positive effect on optimal inventory level. The results on table 4.1 above support the hypothesis which is shown by a standardised coefficient with a value of 1.693 which is positive and is statistically significant at $\mathrm{p}<.05(0.009)$. Therefore, using inventory control systems to control the lead time has a positive and significance effect on maintenance of optimal inventory level.

The fourth hypothesis $\left(\mathbf{H}_{\mathbf{4}}\right)$, states that optimal inventory level has a positive effect on purchasing performance. The results on table 4.1 support the hypothesis which is confirmed by a standardised coefficient with a value of 0.106 which is positive and is statistically significant at $\mathrm{p}<.05$ (0.009). Therefore, the maintenance of optimal inventory levels by means of inventory control systems has a positive and significant effect on purchasing performance in supply chain departments of companies in the mining sector of Zimbabwe. The findings are consistent with the findings of a study in Kenya by NdiranguKung' (2016) who concluded that, companies should implement modern inventory control systems such as Economic Order Quantity (EOQ) and just in time technique (JIT) since they help to maintain optimal inventory levels to enhance supply chain performance.

The fifth hypothesis $\left(\mathbf{H}_{\mathbf{5}}\right)$, states that purchasing performance has a positive effect on organisational performance. The results on table 4.1 support the hypothesis. The results are confirmed by the standardised coefficient with a value of 0.490 which is positive and statistically insignificant at $\mathrm{p}<$ $0.05(0.104)$. Therefore, the practice of inventory management by means of inventory control systems enhances the purchasing performance which in turn will positively but insignificantly improve general organisational performance in the mining sector of Zimbabwe.

Table 4.2 below shows the results on direct effect of inventory control systems on organisational performance.

Table 4.2 Direct Effects - Two Tailed Significance

\begin{tabular}{|c|c|c|}
\hline & $\begin{array}{c}\text { Inventory control } \\
\text { systems }\end{array}$ & $\begin{array}{c}\text { Organisational } \\
\text { Performance }\end{array}$ \\
\hline $\begin{array}{c}\text { Organisational } \\
\text { performance }\end{array}$ & .010 & $\ldots$ \\
\hline
\end{tabular}

Source: Primary (2021)

The results on table 4.2 above support hypothesis $\left(\mathbf{H}_{\mathbf{1 a}}\right)$, which states that inventory control systems have a direct positive effect on organisational performance. This is shown by the standardised coefficient with a value of 0.010 which is statistically significant at $\mathrm{p}<.05(0.000)$. The findings are consistent with the findings in a study conducted in Kenya by Sporta (2018) who identified that inventory control systems have a direct positive effect on organisation performance.

Table 4.3 below shows the results on indirect effect of inventory control systems on organisational performance.

Table 4.3Indirect Effects - Two Tailed Significance 


\begin{tabular}{|c|c|c|}
\hline & $\begin{array}{c}\text { Inventory Control } \\
\text { Systems }\end{array}$ & $\begin{array}{c}\text { Organisational } \\
\text { Performance }\end{array}$ \\
\hline $\begin{array}{c}\text { Organisational } \\
\text { Performance }\end{array}$ & .021 & $\ldots$ \\
\hline
\end{tabular}

Source: Primary data (2021)

The results on table 4.3 above support hypothesis $\left(\mathbf{H}_{\mathbf{1} \mathbf{b}}\right)$, which states that inventory control systems have an indirect positive effect on organisational performance. This is confirmed by a standardised coefficient with a value of 0.021 which is significant at $0.05(0.000)$. Therefore, the results also support the proposed structural equation model 3 in chapter 3 which indicate that inventory control systems can indirectly enhance organisational performance in the mining sector of Zimbabwe. However, the findings show that organisational performance in the mining sector is less influenced directly by inventory control systems $(0.010)$ but is more influenced indirectly through purchasing performance (0.021).The findings on table 4.3 are supported by the findings in a study that was conducted in Ethiopia by Etnafu \& Balda (2018) who identified that, inventory management systems have an indirect effect on organisational performance through supply chain performance.

\section{CONCLUSION AND RECOMMENDATIONS}

Based on the findings of the study, it can be concluded that inventory control systems have direct and indirect positive effect on organisational performance in mining companies. It also be concluded that inventory control systems that have been used in this study have a positive effect on purchasing performance in mining companies. In addition, inventory control systems also help to improve the profitability, production output and cost efficiency of mining companies in Zimbabwe. Therefore, mining companies in Zimbabwe are recommended to implement modern inventory control systems such as the Enterprise Resource Planning (ERP), Continuous Review System (CRS), Periodic Review System (PRS), Distribution Requirement Planning (DRP), Just in Time (JIT) and the Economic Order Quantity (EOQ) for efficient inventory control practices. These inventory control systems enable mining companies to effectively control the lead time which facilitates the maintenance of optimal inventory levels.

\section{REFERENCES}

[1] Adeyemi, S. L. \& Salami, L.O., (2010). Inventory management: A tool of optimizing resources in a manufacturing industry. Journal of Social Science

[2] Andriolo, A., Battini, d., Grubbström, R. W., Persona, A., \& Sgarbossa, F., (2014)A century of evolution from Harriss basic lot size model: Survey and research agenda, International Journal of Production Economics, (155), 16-38. http://dx.doi.org/10.1016/j.ijpe.2014.01.013

[3] Anton Dolinsky (2007), Barcodes, sales and inventory control Retrieved $22 \quad$ Jun 2013 http://www.almyta.com/Inventory_Management_History_4.asp

[4] Akindipe, O. S. (2014). Inventory Management: A Tool for Optimal use of Resources and Overall Efficiency in Manufacturing SMEs. Journal of Entrepreneurship and Innovation (JEMI)
[5] American Production and Inventory Control Society (APICS), (2001)

[6] Ahmad, N.M.N.N., Nawawi, A. \& Salin, A.S.A.P. (2016), "The relationship between human capital characteristics and directors' remuneration of Malaysian public listed companies", International Journal of Business and Society,

[7] Akkermans, H.A., Bogerd, P., Yucesan, E., \& van Wassenhove, L.N. (2003). The impact of ERP on supply chain management: Exploratory findings from a European Delphi study. European Journal of Operational Research,

[8] Alm, N. (2000).Bank Management (4th Ed). Fort Worth: Dryden Press.

[9] Anichebe, N. A. \& Agu, O. A. (2013). Effect of Inventory Management on Organizational Effectiveness.Information and Knowledge Management

[10] Atnafu, D., \& Balda, A. (2018). The impact of inventory management practice on firms' competitiveness and organizational performance: Empirical evidence from micro and small enterprises in Ethiopia. Cogent Business \& Management

[11] Babbie, E. R., (2012). The Basics of Social Research. 6 ed. s.l.: Cengage.

[12] Ballon, R. H. (2000). Business logistics/supply chain management. Planning, organizing and controlling the supply chain (5th ed.). USA: Pearsons-Prentice Hall

[13] Barwa, M. T., (2015) Inventory Control as an Effective DecisionMaking Model and Implementations for Company's Growth. International Journal of Economics, Finance and Management Sciences

[14] Bawa, S., Asamoah, G.E., \& Kissi, E., (2018), Impact of inventory management on firm performance: A case study of listed manufacturing firms in Ghana. DOI: 10.5923/j.ijfa.20180704.01

[15] Bell, J., (2005). Doing Your Research Project: A guide for firsttime researchers in education, helath and social scinece. 4th ed. Berkshire: Open University Press.

[16] Berthod, O. (2017) 'Global Encyclopedia of Public Administration, Public Policy, and Governance', pp. 1-5. doi: 10.1007/978-3-319-31816-5.

[17] Broatch, M. (2001).Making the ERP connection. Computerworld New Zealand, July.

[18] Bowersox, D. J. (2002). Supply chain - Logistics management. International edition. USA: M C Graw Hill.

[19] Byrne, B.M. (2010). Structural Equation Modeling with AMOS: Basic Concepts, Applications, and Programming (2nd Edition). New York: Taylor and Francis Group Publication.

[20] Cagliano, A. C., DeMarco, A., Rafele, C. \& Volpe, S. (2011). Using System Dynamics in Warehouse Management: A Fastfashion Case Study. Journal of Manufacturing Technology Management

[21] Carr, A. S., \& Pearson, J. N. (2002).The impact of purchasing and supplier involvement in strategic purchasing and its impact on firm's performance.International Journal of Operations \& Production Management.

[22] Chen, I.J. (2001). Planning for ERP systems: Analysis and future trend.Business Process Management Journal.

[23] Chen, I. J., Paulraj, A., \& Lado, A. A. (2004). Strategic purchasing, supply management, and firm performance. Journal of Operations Management.

[24] Chitale A.K \& Gupta R.C (2014), materials management supply chain perspective (6th edition) PHI learning private limited, New Delhi.

[25] Cho, J. \& Dansereau, F. (2010), "Are transformational leaders fair? A multi-level study of transformational leadership, justice perceptions, and organizational citizenship behaviours", The Leadership Quarterly, Vol. 21 No. 3, pp. 409-421

[26] Choi, T. (2012). Handbook of EOQ inventory problems Stochastic and deterministic models and applications. New York, Heidelberg, Dordrecht, London: Springer.

[27] Chuang, H.H.C. \& Oliva, R. (2015), "Inventory record inaccuracy: causes and labour effects", Journal of Operations Management

[28] Cohen, L., Manion, L. \& Morisson, K., (2007). Research in education. 6th ed. Routledge 
[29] Confederation of Zimbabwe Industries Mining Sector Survey Report, (2018)

[30] Creswell, J. W. (2014). Research design: qualitative, quantitative and mixed approaches. Los Angeles: Sage Publications

[31] Ciudad-Gómez, A., \& Valverde-Berrocoso, S. J. (2014). Reliability Analysis of an Evaluation Rubric for University Accounting Students: A Learning Activity about Database Use. Journal of International Education Research, Volume 10, Number 5(Special Issue 2014)

[32] DiMaggio, P., \& Powell, W. (1983). The Iron Cage Revisited: Institutional Isomorphism and Collective Rationality in Organizational Fields. American Sociological Review

[33] Dimitrios, P. (2008). The effect of inventory management on firm performance. International Journal of Productivity and Performance Management

[34] Dr. Euginen,C., \& Rubha.S., (2017).“AN OVERVIEW ABOUT JIT (JUST-IN-TIME) - INVENTORY MANAGEMENT SYSTEM." International Journal of Research - Granthaalayah, 5(4)SE, 14-18. https://doi.org/10.5281/zenodo.569368.

[35] Chandler, D., \& Hwang, H. (2015). Learning from Learning Theory: A Model of Organizational Adoption of Organizational Strategies at the Micro Foundations of Institutional Theory. Journal of Management,

[36] Donselaar, K.H. van, (1989) Material Coordination under Uncertainty, Eindhoven University of Technology, Eindhoven, The Netherlands.

[37] Donselaar, K.H. van, (1990) "Integral stock norms in divergent systems with lot-sizes", European Journal of Operations Research

[38] Drurry, C. (2004). Management and cost accounting . London: Prentice hall.

[39] Ellram, L. M. (1996). The Use of the Case Study Method in Logistics Research.Journal of Business Logistics.

[40] Feinstein, A. H., \& Stefanelli, J. M., (2000) Selection and Procurement for the Hospitality Industry. $5^{\text {th }}$ Edition. John Wiley \& Sons: New York, USA

[41] Forrester, J.W., Industrial Dynamics, MIT Press, Cambridge, MA, (1961).

[42] Gitman, L. J. (2009). Principles of managerial finance (12th ed.). Bostos, MA: Pearson Prentice Hall.

[43] Gefen D. (200).A Multi-level Approach to Measuring the Benefits of an ERF System in Manufacturing Firms. Information Systems management

[44] Gratton, C. and Jones, I., (2010). Research Methods for Sports Studies. 2nd ed. Oxon: Routledge.

[45] Golafshani, N. (2003) 'Understanding Reliability and Validity in Qualitative Research', 8(4), pp. 597-606.

[46] Goldratt, M. E. (2004). The goal: A process of ongoing improvement. New York: North River Press

[47] Hair J. F., Bush R. P., and Ortinau D. J. (2003). Marketing Research Within a Changing Information Environment. 2nd Edition. McGraw-Hill Companies.

[48] HassabElnaby, H. R., Hwang, W., \& Vonderembse, M. A., (2012), "The impact of ERP implementation on organizational capabilities and firm performance", Benchmarking: An International Journal, Vol. 19

[49] Hopp, W. J. \& Spearman, M. L. (2000)."Factory Physics". Boston: McGraw-Hill/Irwin

[50] Hutchins, D. (1999). Just in time. UK: Gower Publishing, Ltd

[51] Hoyle, R.H. (1995). Structural equation modeling: Concepts, issues, and applications. London: SAGE.

[52] Johnson, F., \& Ruankaew, T., (2017) A Study of Inventory Control Systems by Jamaican SMEs in Retail and Manufacturing/Distribution Industries. International Journal of Business and Management

[53] Kakeeto, F., Micheal, T., Pastor, K., \& Osunsan, O. K., (2017). Inventory Management and Organizational Profitability at Gumutindo Coffee Cooperative Enterprise Limited, Uganda. International Journal of Business and Management Invention

[54] Kauppi, K. (2013). Extending the Use of Institutional Theory in Operations and Supply Chain Management Research Review and
Research Suggestions. International Journal of Operations \& Production Management

[55] Kakwezi, D. \& Nyeko, P. K. (2014). Procurement Processes and Performance: Efficiency and Effectiveness of the Procurement Function

[56] Kazim, S. (2008).inventory inaccuracy and performance of collaborative supply chain practices. Industrial management and data systems.

[57] Khan S. (2010). Supplier choice criteria of executing agencies in developing countries."16, 4/5; ABI/INFORM Global. The International Journal of Public Sector Management

[58] Klenke, K., (2008). Qualitative Research in the Study of Leadership. Bingley: Emrald.

[59] Koumanakos, D.P (2008). The effect of inventory management on firm performance International Journal of productivity and performance Management, Emerald Group Publication

[60] Kolawole, A. D., Akomolafe, A. B., \& Olusipe, B. J., (2019) Inventory Management: An Impetus for Increased Profitability in Manufacturing Firms. International Journal of Accounting, Finance \& Risk Management. Vol. 4, No. 4, 2019, pp. 110-115. doi: 10.11648/j.ijafrm.20190404.12

[61] Kwame, K. (2007). Working Capital Management Practices of Small Firms in the Asharti Region of Ghana. Retrieved September 15, 2015 from http://www.ssrn.com

[62] Lantai, T. (no date) 'University of Stavanger'.

[63] Lazaridis, I. \& Tryforidis, D. (2006).Relationship between Working Capital Management and Profitability of Listed Companies in the Athens Stock Exchange. Journal of Financial Management and Analysis

[64] Lysons, K and Gillingham, M. (2003). Purchasing and supply chain management. London:Prentice Hall

[65] Lumsden, K. (2012). Logistikens Grunder. (3. uppl.). Lund: Studentlitteratur AB.

[66] Lwiki T., Ojera P. B., Mugend N., \& Wachira N., (2013), "The impact of inventory management practices on financial performance of sugar manufacturing firms in Kenya", International Journal of Business, Humanities and Technology

[67] Lysons, K., \& Farrington, B., (2016). Purchasing and Supply Chain Management, 9th Edition, England

[68] Macdonald, J. (2019).Production Accounting and Inventory Management: a Digital Transformation Approach in Mining Operations. AVEVA Group, UK

[69] Magee, J.F., Production (1985) Planning and Inventory Control, McGraw-Hill, New York, NY

[70] Mathuva, D. (2010). The Influence of Working Capital Management Components on Corporate Profitability: A Surveyon Kenyan listed firms. Research Journal of Business Management

[71] Meindl, P., Chopra, S., (2010) Supply Chain Management STRATEGY, PLANNING, AND OPERATION. $5^{\text {th }}$ Edition: Prentice Hall. U.S.A

[72] Mohamad, A. (2011). "Working Capital Management and Profitability: Evidence from Iran”.World Applied Sciences Journal

[73] Moore, L. J., Lee, S. M. \& Taylor, B. W. (2003).Management Science. Needham: Allyn and Bacon

[74] Mwangi, L., (2016). The effect of inventory management on firm profitability and operating cash flows of Kenya breweries limited, beer distribution firms in Nairobi county: A Research Project Submitted in Partial Fulfilment of the Requirements for the Award of the Degree of Master of Science in Finance, School of Business, University of Nairobi.

[75] Nachtigall, C., Kroehne, U., Funke, F., \& Steyer, R., (2003). Pros and Cons of Structural Equation Modeling: Methods of Psychological Research Online 2003, Vol.8, No.2, pp. 1-22

[76] NdiranguKung'u, J., (2016) Effects of Inventory Control on Profitability of Industrial and Allied Firms in Kenya. IOSR Journal of Economics and Finance (IOSR-JEF)

[77] Neely, A.D., Gregory, M., Platts, K., (1995). Performance measurement systems design: a literature review and research agenda. International Journal of Operations \& Production Management 
[78] Neely, A. D., (199, 'The performance measurement revolution: why now and where next', International Journal of Operations and Production Management

[79] Nkwankwo, O. \& Osho, G. S. (2010). An Empirical Analysis of Corporate Survival and Growth: Evidence from Efficient Working Capital Management. International Journal of Scholarly Academic Intellectual Diversity

[80] Nyabwanga, R. N., \& Ojera, P. (2012).Inventory Management Practices and Business Performance for Small-Scale Enterprises in Kenya. Journal of Business Management

[81] Nunnally, J. C. and I. Bernstein (1994)."The assessment of reliability." Psychometric theory 3: 248-292.

[82] Ogbo, A.I. (2011). Production and Operations Management. Enugu: De-verge Agencies Ltd.

[83] Ogbo, A. I.,Onekanma I.V. \& Wilfred I. U. (2014).The Impact of Effective Inventory Control Management on Organisational Performance: A Study of 7 up Bottling Company NileMile Enugu, Nigeria.Mediterranean Journal of Social Sciences, MCSER Publishing, Rome-Italy

[84] Ogbo, A. I. \& Ukpere, W. I. (2014) "The Impact of Effective Inventory Control Management on Organisational Performance: A Study of 7up Bottling Company Nile Mile Enugu, Nigeria", Mediterranean Journal of Social Sciences, 5 (10), p.109

[85] Oliveira, J., \& Rodrigues, P. C. (2008).Study of Management of Intermediate Inventory in the Manufacture of Paper Products in Brazilian Companies. In: Proceedings of POMS 19th Annual Conference, La Jolla/California.

[86] Orlicky, J., Materials Requirements Planning, McGraw-Hill, New York, NY, 1975

[87] Pandey, I. M. (2008). "Financial Management", 10th Edition. New Delhi: VikasPublishingHousePvt.Limited

[88] Peterson, R. \& Joyce, E. A. 2007.Decision Systems for Inventory Management and Production Planning. New York: John Wiley and Sons

[89] Prempeh, K.B. (2016). The impact of efficient inventory management on profitability: evidence from selected manufacturing firms in Ghana. International Journal of Finance and Accounting

[90] Porter, M.E. (1980). Competitive strategy: Techniques for Analysing, Industried and Competitiors New York: The Free Press

[91] Rajeev, N. (2008). an evaluation of inventory management in indian machine tool SMEs: An exploratory. 4th IEEE International Conference on Management of Innovation and Technology. Bank, Thailand: bank.

[92] Randeree, K. \& Al Youha, H. (2009), "Strategic management of performance: an examination of public sector organizations in the United Arab Emirates", International Journal of Knowledge, Culture and Change Management, Vol. 9 No. 4

[93] Rashid, M. A., Hossain, L., \& Patrick, J.D., (2002) The Evolution of ERP Systems: A Historical Perspective: Idea Group Publishing

[94] Ray, W., (2012). Methods Toward a Science of Behavior and Experience. Belmont: Wadsworth.

[95] Rossetti, C., \& Choi, T. Y. (2005). On the Dark Side of Strategic Sourcing : Experiences from the Aerospace Industry.

[96] Ryan, G., Emmerling, R.J. \& Spencer, L.M. (2009), "Distinguishing high-performing European executives: the role of emotional, social and cognitive competencies", Journal of Management Development, Vol. 28

[97] Rushton.A. (2010). The Handbook of Logistics andDistribution Management.2nd Edition.Kogan Page Ltd. USA

[98] Sahari, S., Tinggi, M. \& Kadri, N. (2012). Inventory management in Malaysian construction firms: Impact on performance. SIU Journal of Management

[99] Salahudden, L. A., \& Abraham, O. A., (2018) Effect of Inventory Management System on Operational Performance in Manufacturing Firms: Study of May and Baker Manufacturing Industry Nig Ltd, Lagos. IRE Journals, Volume 2 Issue 5, ISSN: 2456-8880

[100] Salawati, S., Tinggi, M., \& Kadri, N. (2012).inventory management in malasyianconstrucion firms: impact on performance. SIU Journal management
[101] Saleemi N. A. (1993). Business Finance Simplified. Nairobi: Saleemi Publications Limited

[102] Sandberg, E. (2007). Logistics collaboration in supply chains: practice vs. theory. International Journal of Logistics Management, 18 (2), pp. 274-293.

[103] Saunders, M. \& Tosey, P., (2012).The layers of research desgin. Rapport, pp. 58-59.

[104] Saunders M, \& Lewis P, T. A. (2016) Research Methods for Business Students. 7th edn. Essex: Pearson Education Limited.

[105] Saunders, M., Lewis, P. \& Thornhill, A., (2003).Research methods for business students. 3rd ed. Harlow: Prentice Hall.

[106] Sekaran, U., (2003). Research Methods for Business: $4^{\text {th }}$ Edition. Hermitage Publishing Services. U.S.A

[107] Setyaningsih S. \& Basri M. H., (2013).Comparison continuous and periodic review policy inventory management system formula and enteral food supply in public hospital bandung. International Journal of Innovation, Management and Technology

[108] Shah N. H \& M. Mandeep (2016), "Optimal Inventory Control and Management Techniques"United states: IGI Global publisher

[109] Shin, S., \& Ennis., (2015). A study of relationship between inventory management efficiency and profitability: U.S.A manufacturing industry. Mississippi State University, Meridian

[110] Sitienei, E \& Memba, F. (2015), the effect of inventory management on profitability of cement manufacturing companies in Kenya: A case study of listed cement manufacturing companies in Kenya. International Journal of Management and Commerce Innovations ISSN 2348-7585 (Online) Vol. 3

[111] Stevenson, B. (2010). Operations management (10th ed.). New York: McGraw-Hill Publishing.

[112] Schonsleben, P., (2007) Integral logistics management. $3^{\text {rd }}$ Edition. Operations and Supply Chain Management in Comprehensive Value-Added Networks: Auerbach Publications. New York

[113] Silver, E.A. \& Peterson, R., (1985) Decision Systems for Inventory Management and Production Planning, John Wiley \& Sons, New York, NY.

[114] Sporta, F. O., (2018). Effect of Inventory Control Techniques on Organization's Performance at Kenya Medical Supplies Agencies. The International Journal Of Business \& Management (ISSN 2321-8916)

[115] Sumil B. \& Sameer, P. (2007). International Purchasing, Inventory Management and Logistics London: Prentice Hall

[116] State of The Mining Industry Survey Report, (2018)

[117] Tomal, D.R. \& Jones, K.J. (2015), "A comparison of core competencies of women and men leaders in the manufacturing industry", The Coastal Business Journal

[118] Umble, M., Umble, E., \& Murakami, S. (2006). Implementing theory of constraints in trading Japanese manufacturing: The case of Hitachi Tool engineering. International Journal of production research

[119] Walliman, N., (2011).Research methods, the basics. New York U.S.A:Routledge:

[120] Waters, C.D.J., (2003). An introduction to supply chain management - 2nd Edition. Chichester: Palgrave Macmillan

[121] Yin, R., (1984). Case Study Research: Design and Methods. Beverly Hills: Sage Publication.

[122] Zhang, X., (2005). Delayed demand information and dampened bullwhip effect. Operations Research Letters

[123] Zhang Z. (2005) A Framework for ERP Systems Implementation in China: An Empirical Study. International of production Economics

[124] Zimbabwe Mining Performance Report, (2019)

[125] Zimbabwe Economic Report, (2018)

[126] Mining Zimbabwe Magazine, (2019)

[127] Zinbarg,M. (2005), Research methods.(1st Edition).New Jersey: Pearson Publishers.NewJersy.

[128] Zuva, B., \& Choga, F., (2019) Inventory Management System and Business Performance: Case of Zimbabwean Mining Sector. IOSR Journal of Business and Management (IOSR-JBM) 